\title{
THE SIGNIFICANCE OF SOURCE VERSUS PROCESS IN THE TECTONIC CONTROLS OF MAGMA GENESIS
}

\author{
RICHARD J. ARCULUS \\ Department of Geological Sciences, University of Michigan, Ann Arbor, MI 48109-1063, U.S.A.
}

(Received July 4, 1986; revised and accepted September 26, 1986)

\begin{abstract}
Arculus, R.J., 1987. The significance of source versus process in the tectonic controls of magma genesis. In: S.D. Weaver and R.W. Johnson (Editors), Tectonic Controls on Magma Chemistry. J. Volcanol. Geotherm. Res., 32 : $1-12$.

Despite the association of certain characteristic trace-element signatures with particular tectonic environments of eruption, there are accumulating data which would result in significant tectonic misassignments. Ambiguity of signals appears in active arc/back-arc systems of the southwestern Pacific and particularly in some intracontinental plate suites. Given the selective preservation of continental as opposed to oceanic lithosphere, inappropriate paleotectonic inferences are probable using trace-element criteria alone.

Strong relative fractionation of the alkalis and alkaline earth elements (AEE) with respect to the rare earth elements (REE) in the majority of arc-related magmas and a number of intraplate continental basalts is strongly suggestive of the involvement of hydrous fluids at some stages in the respective petrogenetic processes occurring in these two tectonic regimes. In contrast, fractionation of high-field-strength elements (HFSE) such as $\mathrm{Nb}$ and $\mathrm{Ta}$ with respect to the REE in the same suites is most readily explained by the involvement, at some stage in the magma formation process, of high- $\mathrm{SiO}_{2}$ melts. A number of widely applied tectonic discriminants makes use of AEE/HFSE fractionation, but the processes and sources involved in subduction-zone petrogenesis may be duplicated during interaction of mantle-derived basalt with the heterogeneous components of continental lithosphere, both mantle and crust. A significant role for both volatile-dominated fluids and silicate melts is implicated in collision and some intracontinental plate magmatism.
\end{abstract}

\section{Introduction}

Petrologists have been aware of the association of distinct geochemical characteristics with specific geographic and tectonic environments practically since the inception of petrographic and analytical studies. More recently, with the advent of high-quality and abundant trace-element and isotopic data, considerable effort has been expended in attempts not only to fingerprint particular tectonic environments of eruption but also by inversion of the data to determine the nature of the magma sources and petrogenetic processes involved.

There seems to be little remaining doubt that particular trace-element abundance patterns and isotopic signatures are associated with different eruption environments from spreading ridge through to subduction- and hot-spotrelated centers of activity. Controversy abounds over the detailed petrogenetic interpretation of these data. There are also some ambiguities in the uniqueness of tectonic association of certain geochemical signatures that pose interest- 
ing problems not only in genetic terms but also with respect to possible paleotectonic (mis) interpretations.

\section{Consistency and distinctiveness of chemical pattern}

In a seminal contribution, Chayes (1965) pointed out a distinct difference in terms of major-element geochemistry between what would now be termed hot-spot and subductionrelated volcanics, specifically with respect to the higher $\mathrm{TiO}_{2}$ contents of the former at any given $\mathrm{SiO}_{2}$ concentration or $\mathrm{Mg} \#$. The major-element geochemistry and relative volumetric abundance of evolved rock types (intermediate and high- $\mathrm{SiO}_{2}$ ) can be generally distinctive of some tectonic environments (e.g. Gill, 1981) but on the whole, major-element geochemical discrimination has unfortunately been much less successful when applied to basaltic rocks (cf. Pearce et al., 1977). For example, although hot-spot and subduction-related magmas can be fairly readily distinguished on the basis of $\mathrm{TiO}_{2}$ contents, there is extensive overlap between spreading ridges (both major ocean and backarc basin) and island arcs in these terms (Perfit et al., 1981). The available data seem to indicate that the major-element geochemistry of the products of melting of the upper mantle is similar irrespective of the exact locus of melting (i.e. basaltic), and it is only with respect to the more refined detail of minor-element, traceelement and isotopic characterization that subtle differences appear from one tectonic environment to another.

The most successful discriminations on traceelement grounds depend on the relative fractionation of the alkaline earths (AE) and highfield-strength element to (HFSE) such as $\mathrm{Nb}$, $\mathrm{Ta}, \mathrm{Zr}$ and $\mathrm{Th}$. Variants of presentation from binary through to ternary plots, factorial analysis and normalized "spidergrams" have been employed (e.g. Pearce and Cann, 1973; Wood et al., 1979; Pearce, 1982). Although it is important to be aware of the dangers of normalized data projections when assessment of similarity is made (Wright, 1974), the robustness of many trace-element abundance ratios do permit successful attribution of tectonic environment with known data sets as test cases, and inspire some confidence in the use of discriminant diagrams.

It is also clear however, that the attribution success rate is generally highest in cases where the sites of eruption are remote from continental crust and subcontinental lithospheric mantle (Arculus and Johnson, 1981; Duncan, 1987; Pearce, 1987), and severe misidentification of tectonic environments can arise where magma genesis and passage involves these components. It would appear for example that the fractionation and relative enrichments of $K, R b$, $\mathrm{Sr}$ and $\mathrm{Ba}$ with respect to HFSE that are characteristic of basaltic arc magmas, can be reproduced during the genesis of continental flood basalts such as those of the Columbia River Plateau and Siberian Traps (Arculus and Johnson, 1981), the Karoo (Duncan, 1987) and on the flanks of the nascent North Atlantic during the lower Tertiary in northwest Britain (Thompson et al., 1986).

In terms of correct assignment of paleoenvironment of eruption of volcanic suites, the high probability of error for those associated with continents is disturbing, because it is precisely this type of crust that is most readily conserved in the plate-tectonic cycle and, consequently, the most accessible to geologic study. As a result, quite clearly incorrect paleotectonic reconstructions can be and no doubt have already been made which may not be of great concern to some geochemists and petrologists, but have significant importance for studies of continental growth, structure and economic potential.

Another example of the potential pitfalls in the desirable interweaving of tectonics and petrogenesis is the possibility of error in the application of the " $\mathrm{K}_{2} \mathrm{O}$ at specific wt. $\% \mathrm{SiO}_{2}$ versus depth to subduction zone (K-h)" relationship. Although the K-h tectonic relationship is of fairly widespread applicability in existing plate collision regimes (Gill, 1981), 
enough exceptions are known that independent confirmation of subduction polarity should be sought (Arculus and Johnson, 1978; Foden and Varne, 1980). The fact is that the origin of coupled variations of $\mathrm{K}_{2} \mathrm{O}$ contents and depths to Benioff Zones is very poorly understood, and may in fact result from the interactions of several processes, any one of which may be subject to disturbance in individual arcs.

The critical question arising from these observations is how frequently does incorrect assignment occur at present, and what failure rate is acceptable for paleotectonic reconstructions (Pearce, 1987). It is worth emphasizing, however, that the conservation of continental lithosphere as opposed to the mantle recycling of oceanic lithosphere means that the critical success rate is essentially that for continental magmatism. Also deserving of mention is the danger of assuming that the diagnostic traceelement discriminants employed for Recent to Tertiary volcanics can be used unambiguously for substantially older suites, especially those for Proterozoic and Archean age. The combination of secular change in the geochemistry of crustal growth and evolution of continental lithosphere, changes in thermal structure and changes in the nature of contamination processes within that lithosphere (Taylor and McLennan, 1985) could result in significantly different trace element signatures of intracontinental magmas compared with the presentday.

\section{Examples of discriminant-straddling suites}

Some examples of tectonic assignment problems are useful as a basis for discussion of the relative significance of processes and sources in the development of characteristic trace element signatures. In Fig. 1, critical data for a suite of basalts from the Witu Islands of Papua New Guinea are projected into the discriminant diagrams of Pearce and Cann (1973) and Pearce (1975). The Witu Islands lie about 100

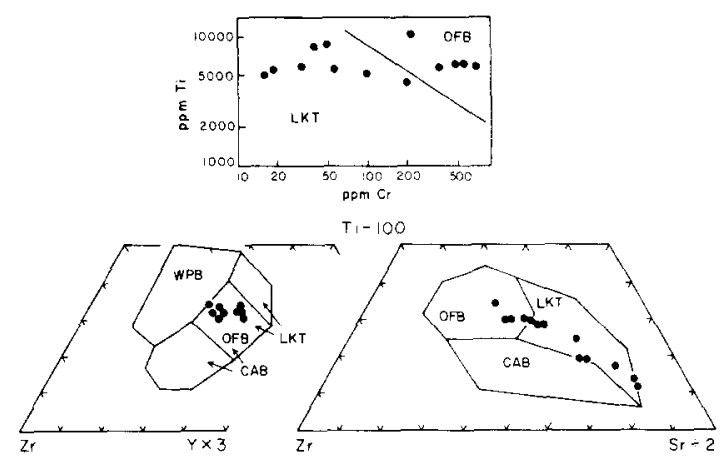

Fig. 1. Trace-element data for basaltic rocks of the Witu Islands, Papua New Guinea (Johnson and Arculus, 1978) projected in the Ti vs Cr diagram of Pearce (1975), and Ti$\mathrm{Zr}-\mathrm{Y}$ and Ti-Zr-Sr diagram of Pearce and Cann (1973). Abbreviations are as follows: $O F B=$ ocean floor basalt; $L K T=$ low-potassium tholeiite; $W P B=$ within plate basalt; $C A B=$ calc-alkalic basalt.

$\mathrm{km}$ northwest of the Willaumez Peninsula of New Britain, in the Bismarck Sea. Overall geochemical coherence with the island-arc volcanics of New Britain, and the superposition of the Witu Islands over the deepest part of the associated Benioff Zone led Johnson and Arculus (1978) to conclude that the islands are indeed part of the New Britain arc. It is noteworthy that in all three of the discriminant plots of Fig. 1 , the data from the Witu Islands either fall within, or straddle, the boundaries between the fields of low-K tholeiites (island-arc type) and ocean floor basalts. The same basalt samples do plot more convincingly in the volcanic arc field alone of the $\mathrm{Cr}-\mathrm{Y}$ discriminant diagram of Pearce (1982). With respect to major elements, it is significant that data for these same samples plot in an extraordinarily diverse number of fields in tectonic discriminants such as that of $\mathrm{MgO}$-total $\mathrm{Fe}$ oxides- $\mathrm{Al}_{2} \mathrm{O}_{3}$ (Pearce et al., 1977).

In cases like this, we are faced with making a choice between holding fast to the notion that trace-element diagnostic signals are consistent, and that the Witu Islands represent a change from arc to spreading ridge environment, or that a mixed, inconsistent signal has resulted despite a uniform tectonic configuration. There is in fact no stratigraphic evidence for a separation 
of magma packages into ocean floor and arctype respectively, and all of the lavas appear to have been erupted within the present collision framework. Of interest is the fact that the Witu Islands are located on the southwestern margin of a vigorously spreading back-arc (Manus) basin (Sinton et al., 1986), and to some extent the mixture of arc and spreading center geochemical signals may be the result of this geographic proximity. A smearing of the traceelement characteristics of divergent and convergent margin volcanics seems to be prevalent in the active margins of the southwestern Pacific Ocean (e.g., Perfit et al., 1987). It is somewhat ironic, in view of the ambiguity of trace-element-based tectonic assignments that can be made for the Witu Islands, that they should have also been chosen by other workers as type examples for calc-alkaline differentiation processes (Grove and Baker, 1984). A final point is that the $\mathrm{K}-\mathrm{h}$ relationships for the New Britain arc as a whole would indicate a north to south subduction polarity for the northern Willaumez Peninsula-Witu Islands segment, which is totally opposite to the true situation (Johnson, 1976).

In strong tectonic contrast with the oceanic setting of the Witu Islands is the active volcanism of the southwestern margin of the Colorado Plateau. The San Francisco Volcanic Field (SFVF) is one of several magmatic centers in the region, and includes a wide spectrum of compositional types from strongly silicaundersaturated basalts through to hypersthene- and quartz-normative basalts, andesites, dacites, rhyolites and trachytes (Moore et al., 1976). The age range of the volcanics is from about $5 \mathrm{Ma}$ to Present (Tanaka et al., 1986) and considerably postdates any plausible passage of the subducted Farallon Plate beneath the region at about 15 Ma before Present (Snyder and Dickinson, 1976). The intermediate volcanics of the SFVF are an example of "anorogenic" (i.e. noncollision) andesites which also occur in several other centers along the southern rim of the Colorado Plateau (Mount
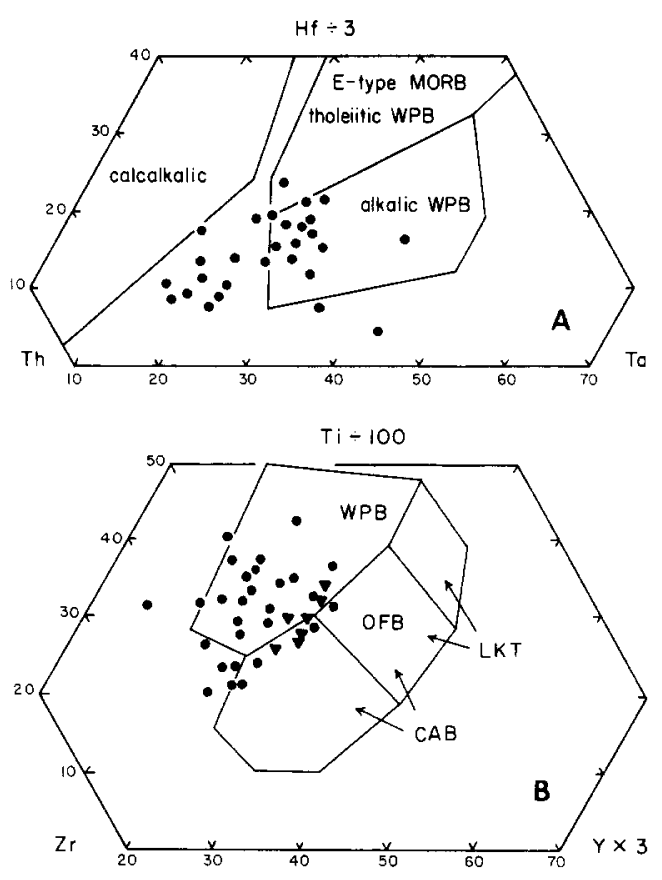

Fig. 2. Trace-element data for basalts of the San Francisco Volcanic Field (SFVF) (circles) and Taos Volcanic Field (triangles) projected in the Hf-Th-Ta diagram (A) of Wood (1979) and Ti-Zr-Y diagram (B) of Pearce and Cann (1973).

Taylor, as described by Baker and Ridley, 1970) and in the Taos Volcanic Field of the Rio Grande Rift (Basaltic Volcanism Study Project, 1981).

Although many of the basalts from the SFVF fall appropriately in the "within-plate" fields of the Hf-Th-Ta and Ti-Zr-Y tectonic discriminant diagrams of Fig. 2, there are some that straddle the boundary zone with "calc-alkalic" basalts in the case of the former or even within the "calc-alkalic" field in the latter diagram. These basalts are interleaved in terms of temporal and spatial distribution in the Field. The andesites of the SFVF are characterized by strong enrichments of the light relative to the heavy rare earth elements (REE), and in the discriminant diagrams of Bailey (1981) would appear to represent a further enhancement of the trends developed in the sequence from intraoceanic to Andean margin arcs (Fig. 3 ).

Shorn of the present-day tectonic controls that can be brought to bear upon the petrogen- 

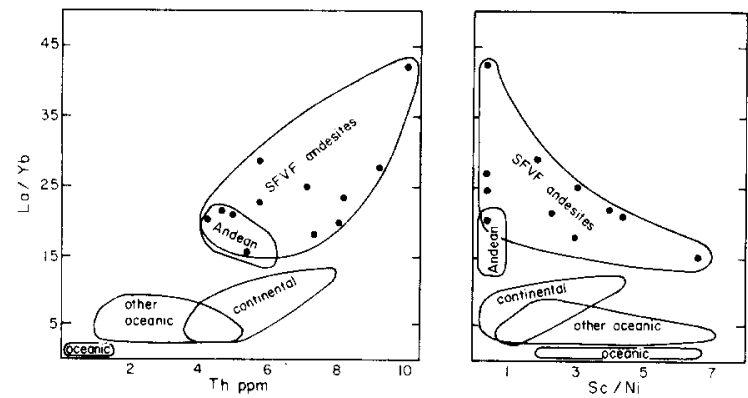

Fig. 3. Trace-element data for andesites of the SFVF compared with other orogenic andesites in the discriminant diagrams of Bailey (1981). Terms on the figure refer to oceanic as intraoceanic without developed basement, other oceanic including mature oceanic arcs, and continental representing arcs on relatively young continental crust. The ordinate is the same for both parts of the figure.

esis of the SFVF, it would be tempting to assume on the basis of an integrated study of the basalts and intermediate volcanics that a major transition from stable within-plate activity to collision-zone, arc-related volcanism had occurred. This of course is remote from the reality of the situation, and the SFVF constitutes another example of constant tectonic but mixed trace-element signature magmatism. The current petrogenetic interpretation of the data is that major interaction between upper mantle-derived basalts and components of the lower continental crust of the Colorado Plateau has taken place, and that much of the development of the intermediate and silicic volcanics is the result of assimilation and fusion of the crust (Gust et al., 1984; Keating and Arculus, 1985). Combined assimilation of and fractional crystallization (AFC) within the crust underlying the Taos Volcanic Field has also been proposed by M.A. Dungan and co-workers (Dungan et al., 1986; McMillan and Dungan, 1986; Thompson et al., 1986) and may account for the straddling by the TVF basalts of the within-plate and calc-alkalic discriminant fields of the Ti-Zr-Y diagram of Fig. 2.

Comprehensive examples of constant-tectonic transdiscriminant volcanics are also presented in this volume by A.R. Duncan for the Karoo, and it would seem that the point is now well established that mixed signals are not rare in magmatic environments. This should be sufficient to give pause to any erstwhile tectonic reconstructors. The more important next step is to examine the possible underlying causes for the generation of these mixed signals.

\section{Distinctive trace-element fractionation}

In many of the examples cited above and also observed by others, ambiguity in terms of tectonic discrimination seems to arise in particular from the relative fractionation of HFSE with respect to the $\mathrm{AE}$, and also from fractionation within the HFSE as a group. For example, there is quite apparently fractionation within the basalts of the SFVF in terms of trace elements that are relatively compatible with major crystalline hosts such as zircon ( $\mathrm{Zr}, \mathrm{Hf}, \mathrm{Th}$ ) and $\mathrm{Fe}-\mathrm{Ti}$ oxides such as ilmenite and rutile $(\mathrm{Nb}$, $\mathrm{Ta}$ ). In general, depletion of the elements that are geochemically coherent with $\mathrm{Ti}$, such as $\mathrm{Nb}$ and Ta (i.e. the TNT group) relative to the REE has come to be regarded as a ubiquitous subduction zone signature. Concurrent with the relative depletion of the TNT elements, the strong relative enrichments of the trace alkalis, $\mathrm{AE}$ and $\mathrm{Pb}$ are also distinctive. However, the abundances of other HFSE like $\mathrm{Zr}$, Th and $\mathrm{U}$ are more variable on an interarc comparative basis (Basaltic Volcanism Study Project, 1981).

There is considerable debate at present over the source of these fractionations and their effects on trace-element discrimination classifications. It is possible that our understanding of the origin of these fractionations will be aided by a comparison of the types of sources and processes that are involved in compressional versus intraplate (especially continental components thereof) magmatism.

In order to explain the alkali and AE enrichments in subduction zone magmas relative to a reference group of coherently behaved trace elements such as the rare earths, current models can be divided basically into the following groups: 
(1) the enrichments result from one-way metasomatic transport of the $\mathrm{AE}$ in supercritical fluids released from the dewatering of the upper layers of a subducted slab, into the overlying mantle wedge (e.g., Kay, 1980; Gill, 1981);

(2) given the similarities between many oceanic intraplate and arc magmas in terms of $\mathrm{AE} / \mathrm{REE}$ ratios, the fractionations may result from contrasts in melting processes in the two environments (e.g., Arculus, 1981; Morris and Hart, 1983); and

(3) the strong AE/REE fractionations observed in many lower continental crustal materials and continental flood basalts suggests that the lower crust may be a very important component in contamination processes (Arculus and Johnson, 1981).

More complex models invoking two or all three of these groups have been proposed (Arculus and Powell, 1986; White and Dupre, 1986; Davidson, 1986; Hickey et al., 1986).

The most important underlying conclusion of this debate seems to be that enrichments of the alkalis and $\mathrm{AE}$ relative to the REE probably indicate the involvement at some stage of a metasomatizing hydrous fluid. Although the agency of this fluid has of course been invoked by many to account for the overall phenomenon of subduction zone volcanism (Gill, 1981), there is also evidence for mobilization of hydrous fluids in other environments such as the subcontinental lithospheric mantle (Hawkesworth et al., 1983, 1984), apparently independent of immediate subduction zone involvement.

The depletions of some HFSE in island-arc basalts with respect to the REE (Fig. 4) have provoked a variety of explanations without a current consensus. Retention of $\mathrm{Nb}$ and $\mathrm{Ta}$ in the subducted slab (e.g., in a rutile-bearing eclogite) is an appropriate corollary of model (1) above (e.g., Saunders et al., 1980). Stabilization of a TNT-bearing phase within the mantle wedge during melting has been proposed by proponents of model (2), and a similar role for rutile or ilmenite in the lower crust

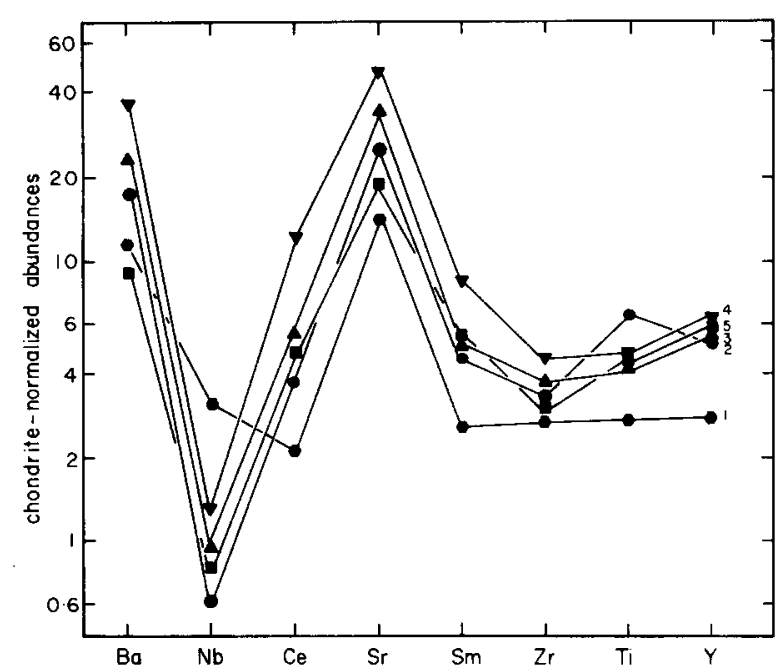

Fig. 4. Chondrite-normalized abundances of selected trace elements of the "type arc suite" of the Basaltic Volcanism Study Project (1981). Numbers on the right-hand side of the patterns refer to suite sample numbers. Normalizing factors in this and subsequent figures are those of Taylor and McLennan (1985).

has been suggested by Arculus and Johnson (1981).

There are difficulties with all of these explanations however, that need to be examined in view of the significance of HFSE abundances and relative fractionations for tectonic discrimination. For example, retention of $\mathrm{Nb}$ and $\mathrm{Ta}$ in the subducted slab does not result in relative fractionation of these elements with respect to the REE in the mantle wedge, unless the REE are transported into the wedge along with the alkalis and AE from the subducted slab. The order of relative mobility required is alkalis $>\mathrm{AE}>\mathrm{REE}>\mathrm{HFSE}$, which is plausible but not altogether consistent with some observations of trace element/isotopic systematics in arc magmas (Arculus and Johnson, 1981). The $\mathrm{REE}$ are known to be potentially mobile in halogen-bearing $\mathrm{CO}_{2}$-rich fluids (e.g., Wendlandt and Harrison, 1979) and may be transported in subduction zones.

The concave-upward normalized abundance patterns in some boninites appear to reflect the selective addition of light REE to the mantle wedge (Jenner, 1981; Hickey and Frey, 1982). 
Furthermore, the light REE-enriched patterns of many arc basalts (e.g., in the Aleutians and Antilles), despite ${ }^{143} \mathrm{Nd} /{ }^{144} \mathrm{Nd}$ values indicative of derivation from long-term light REEdepleted mantle sources, would also seem to be indicative of recent REE mobility in subduction zones (Saunders et al., 1980). However, REE abundances in some tholeiitic arc basalts (e.g., Izu-Honshu and New Britain) are strikingly low (down to $2-5 \times$ chondritic) (Fig. 4) and unfractionated with respect to chondrites. These features do not seem to be consistent with additions of REE from the subducted slab to the primary mantle wedge source.

One of the striking features of the trace-element abundance patterns in these primitive tholeiites however, is the persistence of strongly negative $\mathrm{Nb}$ anomalies with respect to the REE, even at these remarkably low overall REE abundance levels (Fig. 4). Another explanation that has been proposed for the depletion of $\mathrm{Nb}$ and Ta with respect to the REE in arc basalts is that the source peridotites have suffered extensive previous melt extraction, with marked preferential loss of $\mathrm{Nb}$ and $\mathrm{Ta}$ compared with the light REE (Arculus and Powell, 1986; Watson and Ryerson, 1986). Available partitioning data for these elements between the major phases likely to be stable in strongly depleted peridotite, and coexisting melt do not indicate an order of magnitude smaller Kd's for $\mathrm{Nb}$ or Ta compared with La or Ce (Irving and Frey, 1984 ). Furthermore, the same degree of relative fractionation between these element groups persists in strongly alkaline, silica-undersaturated arc magmas such as the feldspathoidal volcanics of the Tabar-Lihir-Tanga-Feni (TLTF) islands, east of New Ireland in Papua New Guinea (Wallace et al., 1983 (Fig. 5). Assuming that these magmas represent lower degrees of partial melting of a peridotite wedge source than the tholeiitic basalts of New Britain, it is surprising that the fractionation of $\mathrm{Nb}$ compared to $\mathrm{Ce}$ is of the same magnitude if the $\mathrm{Kd}$ for $\mathrm{Nb}$ during wedge anatexis is a factor of 5-10 smaller than Ce. At low degrees of partial

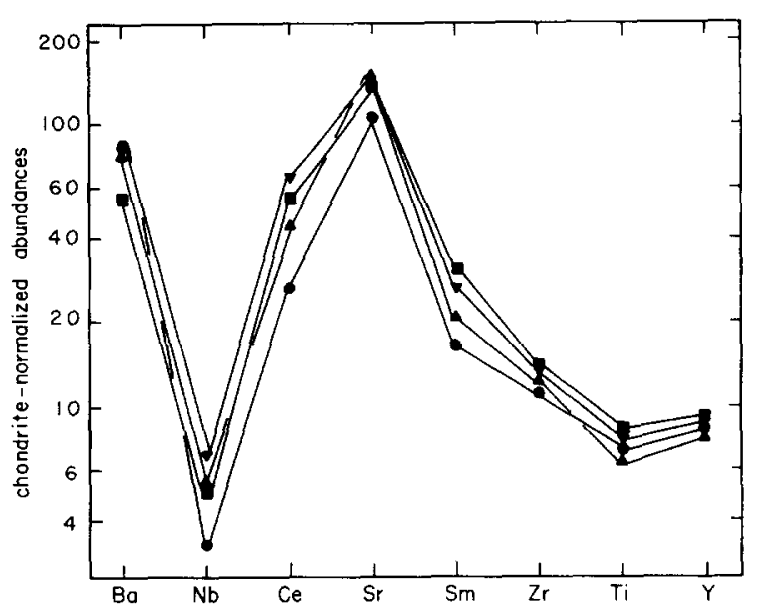

Fig. 5. Chondrite-normalized abundances of selected trace elements in the strongly alkaline lavas of the Tabar-LihirTanga-Feni islands of Papua New Guinea (Wallace et al., 1983).

melting, the degree of relative fractionation of $\mathrm{Nb}$ and Ce should be markedly diminished or even the reverse of that observed.

Retention of the HFSE in the subducted slab no doubt occurs, and relative fractionation of alkalis and AE, REE and HFSE in fluids released from the slab may be important in the genesis of some subduction-related magmas such as boninites. However, the features outlined above for other types of arc magma do not seem consistent with fluid-slab fractionation alone, and alternatives have to be sought. One of these alternatives is the stabilization of a refractory phase in the mantle wedge during melting which results in the preferential retention of the HFSE in the residual solid. A variety of potential phases has been suggested including ilmenite, rutile, sphene, perovskite and chondrodite-related structures (Green, 1981; Morris and Hart, 1983; Wheller et al., 1987). The major difficulty with these proposals is that saturation of a basaltic melt with a phase such as ilmenite or rutile results in high $\mathrm{Ti}$ concentrations in the melt (as observed with high-Ti lunar basalts ), totally opposite to that observed in arc magmas (Fig. 5).

Perovskite is a particularly interesting candidate however, because the relative fractionations of AE-REE-HFSE in arc magmas seem 
consistent with the known distribution coefficients between melts and this phase (Wheller et al., 1987), without the necessity of involvement of any slab-contribution whatsoever. Furthermore, alkaline lavas of the Sunda arc in addition to low $\mathrm{Nb} / \mathrm{La}$ ratios show a consistent positive correlation of $\mathrm{Nb}$ and La despite an essentially constant $\mathrm{Ti}$ content, perhaps consistent with buffering of Ti levels in the mantle source regions by perovskite ( $R$. Varne and J. Foden, pers. commun., 1986). In contrast, no such buffering is observed for equivalent strongly alkaline lavas of Papua New Guinea (Fig. 5 ).

Additional critical observations can be made with respect to a potential role for perovskite:

(1) At pressures $\leq 4 \mathrm{GPa}$, the activity of $\mathrm{SiO}_{2}$ in the mantle is too high to permit the stable existence of perovskite in peridotite (Arculus and Powell, 1986).

(2) At pressures $\geq 4 \mathrm{GPa}$, the combination of residual garnet and perovskite in anatectic events can result in appropriate light/heavy REE and HFSE/REE fractionations (e.g., Fig. 5). Nevertheless, strong $\mathrm{Nb}$ depletions are observed in island arc tholeiites with no indications of the influence of garnet and which were erupted over shallow Benioff Zone depths (Fig. 4).

(3) Perovskite has not been identified in peridotite xenoliths in kimberlites even though barometric calculations indicate pressures of equilibration $\geq 4 \mathrm{GPa}$ (Dawson, 1980).

In view of the difficulties encountered variously with slab retention, refractory phase participation and extreme source depletion as explanations for the observed trace element abundances, it is apparent that more complex models are indicated (Arculus and Powell, 1986). Perhaps the most promising avenue for further progress is offered by the experimental studies of E.B. Watson and colleagues on saturation levels of HFSE in silicate melts, especially with respect to other trace elements such as the AE and REE. In broad summary, it is apparent that saturation levels of elements such as $\mathrm{Zr}, \mathrm{P}$ and $\mathrm{Ti}$ are a strong function of melt structure (i.e. composition), temperature and pressure (Watson, 1979; Watson and Capobianco, 1981; Watson and Ryerson, 1986). Significantly lower concentrations of elements like $\mathrm{Zr}$ are required for zircon saturation in melts of rhyolitic composition than in basalt. In contrast, no such dramatic solubility effects are observed for the larger, less highly charged $\mathrm{AE}$ and REE. As a consequence, significant fractionation of these element groups can take place providing high- $\mathrm{SiO}_{2}$ melts are involved at some stage.

Partial melting of the basaltic and/or sedimentary layers of the subducted slab is certainly one possibility for the genesis of high$\mathrm{SiO}_{2}$ melts in subduction zones. The alternative is melting of basaltic zones trapped within the overturning, convecting peridotite wedge (Arculus and Powell, 1986). Direct evidence for the localized preservation of such materials, at least in the continental lithosphere, comes from the presence of high-pressure eclogites and metasomatized peridotites in kimberlite pipes. Overall thermal structures of subduction zones are probably more favorable for devolatilization of the slab and melting of the wedge rather than direct melting of the slab (Anderson et al., 1978; cf. Marsh, 1979), but in either case, reaction of a high-SiO $\mathrm{Si}_{2}$ melt with surrounding peridotite would buffer the melt to equilibrium basaltic composition (Ringwood, 1974), while retaining the fractionated AE/HFSE values. The overall trace-element abundance patterns could well correspond with those ratios observed for subduction zone magmas.

In summary then, the involvement of fluids as potent agents for $\mathrm{AE} / \mathrm{REE}$ fractionation and silicic melts for AE-REE/HFSE fractionation seem the most attractive working hypotheses. The interesting implication stemming from this conclusion is that neither of these components need be uniquely subduction zone related. For example, with respect to intracontinental plate magmatism, the development of pronounced $\mathrm{AE} / \mathrm{REE}$ and REE/HFSE fractionation in 


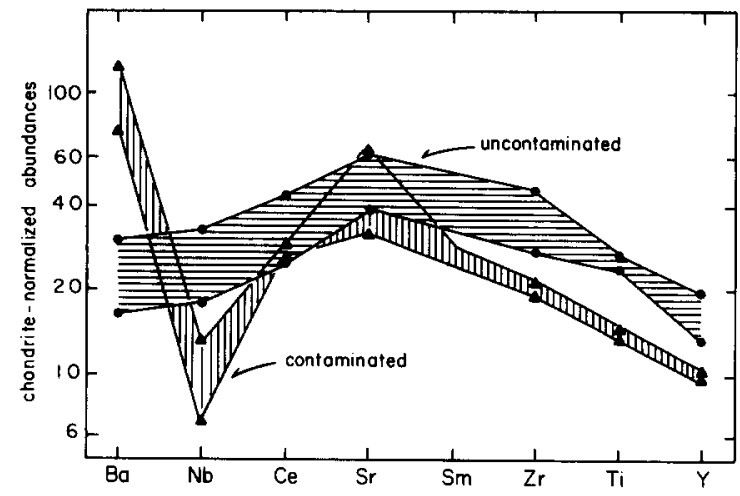

Fig. 6. Chondrite-normalized abundances of pristine mantle-derived and crustally contaminated lavas of the Skye Main Lava Series of the British Tertiary Volcanic Province, after Thompson (1982).

environments remote from subduction zones can perhaps be accounted for if fluid gain and/or silicic melt interactions occur in the source regions or during magma uprise into the continental crust.

Comprehensive studies of the British Tertiary Volcanic Province (BTVP) serve as an example for such processes (Thompson, 1982). In Fig. 6, trace-element data for basaltic lavas that have been recognized on isotopic grounds as reflecting variable degrees of contamination by Precambrian basement are displayed. The interesting features in the current context are the high $\mathrm{Ba} / \mathrm{Ce}$ and low $\mathrm{Nb} / \mathrm{Ce}$ ratios and general dilution of the $\mathrm{REE}, \mathrm{Zr}$, $\mathrm{Ti}$ and $\mathrm{Y}$ of the contaminated compared with the primitive magmas. This latter feature is obscured in Thompson's (1982) presentation by a second normalization to a uniform $\mathrm{Yb}=10 \times$ chondritic. Nevertheless, as proposed by R.N. Thompson and colleagues, it would appear that selective interaction with fluids and silicic melts derived from the continental crust have taken place during this continental rifting episode of the BTVP.

The contamination processes in the case of the BTVP seem to be dominantly crustal but there is reason to believe that similar processes could be involved with petrogenesis in the upper mantle beneath continental regions like southern Africa, as argued in this volume by A.R.
Duncan. Metasomatic transport of the AE has been demonstrated for some eclogite xenoliths from kimberlites in southern Africa (McCormick and Smyth, 1985), and significant fractionation of REE/HFSE/AE has been shown for various high-pressure xenolith populations (Hawkesworth et al., 1986). Melting and interaction with fluids derived from these materials seems reasonable given the thermal disturbance represented by the Karoo episode.

Although melts from the upper mantle are inevitably buffered in terms of major-element composition by peridotite and generally erupted as basalts, the known heterogeneity of mantle lithospheric components permits the generation, at least in restricted and localized amounts, of a much wider variety of melt compositions and fluid components that seem detectable on trace-element and isotopic grounds.

\section{Concluding remarks}

There is no doubt that systematic gathering and interpretation of trace-element data for igneous rocks have revealed many persistent and important links with tectonic processes. Progress in petrogenesis and tectonics has been advanced considerably as a result of these combined efforts. It is clear however, that juxtaposition of potential magma and fluid sources and the incidence of certain magma generation processes can take place in more than one tectonic environment; uncritical acceptance of a set of trace-element signals as being diagnostic of a particular tectonic framework is obviously subject to error, varying in extent from considerable ambiguity in oceanic-collision/back-arc regimes to downright error within continental plates. Paleotectonic reconstructions that ignore these basic constraints should be regarded with suspicion.

\section{Acknowledgements}

The organizers of the International Volcanological Congress are thanked for their invita- 
tion to participate in the meeting and their substantial logistical and tailoring support. Conversations during and after the Congress with Andy Duncan, John Foden, Chris Hawkesworth, Julian Pearce, Roger Powell, Rick Varne and Alan White with respect to intraplate and arc magmatism contributed substantially if without lasting effects to the development of the ideas presented here. The patience of volume editors Steve Weaver and Wally Johnson is much appreciated. Support of NSF grant EAR-8518060 is acknowledged.

\section{References}

Anderson, R.N., DeLong, S.E. and Schwartz, W.M., 1978. Thermal model for subduction with dehydration in the downgoing slab. J. Geol., 86: 731-739.

Arculus, R.J., 1981. Island arc magmatism in relation to the evolution of the crust and mantle. Tectonophysics, 75 : 113-133.

Arculus, R.J. and Johnson, R.W., 1978. Criticism of generalised models for the magmatic evolution of arc-trench systems. Earth Planet. Sci. Lett., 39: 118-126.

Arculus, R.J. and Johnson, R.W., 1981. Island arc magma sources: a geochemical assessment of the roles of slabderived components and crustal contamination. Geochem. J., 15: 109-133.

Arculus, R.J. and Powell, R., 1986. Source component mixing in the regions of arc magma generation. J. Geophys. Res., 91: 5913-5926.

Bailey, J.C., 1981. Geochemical criteria for a refined tectonic discrimination of orogenic andesites. Chem Geol., 32: 139-154.

Baker, I. and Ridley, W.I., 1970. Field evidence and K, Rb, Sr data bearing on the origin of the Mt. Taylor Volcanic field, New Mexico, U.S.A. Earth Planet. Sci. Lett., 10: 106-114.

Basaltic Volcanism Study Project, 1981. Basaltic Volcanism on the Terrestrial Planets. Pergamon, New York, NY, 1286 pp.

Chayes, F., 1965. Titania and alumina content of oceanic and circum-oceanic basalt. Mineral. Mag., 34: 126-131.

Davidson, J.P., 1986. Isotopic and trace element constraints on the petrogenesis of subduction-related lavas from Martinique, Lesser Antilles. J. Geophys. Res., 91: $5943-5962$.

Dawson, J.B., 1980. Kimberlites and their Xenoliths. Springer-Verlag, New York, NY, 252 pp.

Duncan, A.R., 1987. The Karoo igneous province - a problem area for inferring tectonic setting from basalt geochemistry. In: S.D. Weaver and R.W. Johnson (Editors), Tectonic controls on Magma Chemistry. J. Volcanol. Geotherm. Res., 32: 13-34.
Dungan, M.A., Lindstrom, M.M., McMillan, N.J. Moorbath, S., Hoefs, J. and Haskin, L.A., 1986. Open system magmatic evolution of the Taos Plateau Volcanic Field, northern New Mexico: 1, the petrology and geochemistry of the Servilleta basalt. J. Geophys. Res., 91: 5999-6028.

Foden, J.D. and Varne, R., 1980. The petrology and tectonic setting of Quaternary-Recent volcanic centers of Lombok and Sumbawa, Sunda Arc. Chem. Geol., 30: 201-226.

Gill, J.B., 1981. Orogenic Andesites and Plate Tectonics. Springer-Verlag, New York, NY, 390 pp.

Green, T.H., 1981. Experimental evidence for the role of accessory phases in magma genesis. J. Volcanol. Geotherm. Res., 10: 405-422.

Grove, T.L. and Baker, M.B., 1984. Phase equilibrium controls of the tholeiitic versus calc-alkaline differentiation trends. J. Geophys. Res., 89: 3253-3274.

Gust, D.A., Arculus, R.J., Moore, R.B., Wolfe, E.W. and Ulrich, G.E., 1984. Mantle-derived magma interaction with crust and the development of hybrid alkalic-calcalkalic lineages. Geol. Soc. Am., Abstr. with Programs, 16: 526 .

Hawkesworth, C.J., Erlank, A.J., Marsh, J.S., Menzies, M.A. and Van Calsteren, P., 1983. Evolution of the continental lithosphere: evidence from volcanics and xenoliths in southern Africa. In: C.J. Hawkesworth and M.J. Norry (Editors), Continental Basalts and Mantle Xenoliths. Shiva, Nantwich, U.K., pp. 111-138.

Hawkesworth, C.J., Rogers, N.W., Van Calsteren, P.W.C. and Menzies, M.A., 1984. Mantle enrichment processes. Nature, 311: 331-335.

Hawkesworth, C.J., Van Calsteren, P., Rogers, N.W. and Palacz, Z., 1986. Isotope variations in Recent volcanics: a trace element perspective. Int. Volcanol. Congr., New Zealand, (abstr.) p. 165.

Hickey, R.L. and Frey, F.R., 1982. Geochemical characteristics of boninite series volcanics: implications for their source. Geochim. Cosmochim. Acta, 46: 2099-2115.

Hickey, R.L., Frey, F.A., Gerlach, D.C. and Lopez-Escobar, L., 1986. Multiple sources for basaltic arc rocks from the southern volcanic zone of the Andes $\left(34^{\circ}-41^{\circ}\right)$ : trace element and isotopic evidence for contributions from subducted oceanic crust, mantle, and continental crust. J. Geophys. Res., 91: 5963-5984.

Irving, A.J. and Frey, F.A., 1984. Trace element abundances in megacrysts and their host basalts: constraints on partition coefficients and megacryst genesis. Geochim. Cosmochim. Acta, 48: 1201-1221.

Jenner, G.A., 1981. Geochemistry of high-Mg andesites from Cape Vogel, Papua New Guinea. Chem. Geol., 33: 307-332.

Johnson, R.W., 1976. Potassium variations across the New Britain volcanic arc. Earth Planet. Sci. Lett., 31: 104-191.

Johnson, R.W. and Arculus, R.J., 1978. Volcanic rocks of 
the Witu Islands, Papua, New Guinea: the origin of magmas above the deepest part of the New Britain Benioff zone. Bull. Volcanol., 41 (4) : 609-655.

Kay, R.W., 1980. Volcanic arc magmas: implications for a melting-mixing model for element recycling in the crust-upper mantle system. J. Geol., 88: 497-522.

Keating, S.J. and Arculus, R.J., 1985. Thermobarometry of cumulate xenoliths: implications for basalt ponding under the Colorado Plateau, AZ. Geol. Soc. Am., Abstr. with Programs., 17: 624.

Marsh, B.D., 1979. Island arc development: some observations, experiments and speculations. J. Geol., 87: 687-713

McCormick, J.C. and Smyth, J.R., 1985. Alteration in aluminous, mantle derived eclogites. EOS, 66: 386.

McMillan, N.J. and Dungan, M.A., 1986. Magma mixing as a petrogenetic process in the development of the Taos Plateau Volcanic Field, New Mexico. J. Geophys. Res., 91: 6029-6045.

Moore, R.B. Wolfe, E.W. and Ulrich, G.E., 1976. Volcanic rocks of the eastern and northern parts of the San Francisco Field, Arizona, U.S. Geol. Surv., J. Res., 40: $549-560$.

Morris, J.D. and Hart, S.R., 1983. Isotopic and incompatible element constraints on the genesis of island arc volcanics from Cold Bay and Amak Island, Aleutians, and implications for mantle structure. Geochem. Cosmochim. Acta, 47: 2015-2033.

Pearce, J.A., 1975. Basalt geochemistry used to investigate past tectonic environments on Cyprus. Tectonophysics, 25: 41-67.

Pearce, J.A., 1982. Trace element characteristics of lavas from destructive plate boundaries. In: R.S. Thorpe (Editor), Andesites. John Wiley and Sons, New York, NY, pp. 525-548.

Pearce, J.A., 1987. An expert system for the tectonic characterization of ancient volcanic rocks. In: S.D. Weaver and R.W. Johnson (Editors), Tectonic Controls on Magma Chemistry. J. Volcanol. Geotherm. Res., 32: 51-65.

Pearce, J.A. and Cann, J.B., 1973. Tectonic setting of basic volcanic rocks determined using trace element analyses. Earth Planet. Sci. Lett., 19: 290-300.

Pearce, T.H., Gorman, B.E. and Birkett, T.C., 1977. The relationship between major element chemistry and tectonic environment of basic and intermediate volcanic rocks. Earth Planet. Sci. Lett., 36: 121-132.

Perfit, M.R., Gust, D.A., Bence, A.E., Arculus, R.J. and Taylor, S.R., 1981. Chemical characteristics of islandarc basalts: implications for mantle sources. Chem. Geol., 30: 227-256.

Perfit, M.R., Langmuir, C.H., Baekissapa, M., Chappell, B.W., Johnson, R.W., Staudigel, J. and Taylor, S.R., 1987. Geochemistry of volcanic rocks from the Woodlark Basin: addressing the questions of ridge subduction and a reversal in the polarity of subduction. J. Geophys. Res., in press.

Ringwood, A.E., 1974. The petrological evolution of island arc systems. Geol. Soc. London. J., 130: 183-204.

Saunders, A.D., Tarney, J. and Weaver, S.D., 1980. Transverse geochemical variations across the Antarctic Peninsula: implications for the genesis of calc-alkaline magmas. Earth Planet. Sci. Lett., 46: 344-360.

Sinton, J.M., Liu, L., Taylor, B. and Chappell, B.W., 1986. Petrology, magmatic budget, and tectonic setting of Manus back-arc lavas. EOS, 67: 377.

Snyder, W.S. and Dickinson, W.R., 1976. Tectonic implications of space-time patterns of Cenozoic magmatism in the western United States. Earth Planet. Sci. Lett., 32: 91-106.

Tanaka, K.L., Shoemaker, E.M., Ulrich, G.E. and Wolfe, E.W., 1986. Migration of volcanism in the San Francisco Volcanic Field, Arizona. Geol. Soc. Am. Bull., 97: 129-141.

Taylor, S.R. and McLennan, S.M., 1985. The Continental Crust: its Composition and Evolution. Blackwell, Oxford, $312 \mathrm{pp}$.

Thompson, R.A., Dungan, M.A. and Lipman, P.W., 1986. Multiple differentiation processes in early-rift calcalkaline volcanics, northern Rio Grande Rift, New Mexico. J. Geophys. Res., 91: 6046-6058.

Thompson, R.N., 1982. Magmatism of the British Tertiary Province. Scott. J. Geol., 18: 49-107.

Thompson, R.N., Morrison, M.A., Dickin, A.P., Gibson, I.L. and Harmon, R.S., 1986. Two contrasting styles of interaction between basic magmas and continental crust in the British Tertiary Volcanic Province. J. Geophys. Res., 91: 5985-5998.

Wallace, D.A., Johnson, R.W., Chappell, B.W., Arculus, R.J., Perfit, M.R. and Crick, I.H., 1983. Cainozoic volcanism of the Tabar, Lihir, Tanga, and Feni Islands, Papua New Guinea. BMR Rep. 243: Microform MF197.

Watson, E.B., 1979. Zircon saturation in felsic liquids: experimental data and applications to trace element geochemistry. Contrib. Mineral. Petrol., 70: 407-419.

Watson, E.B. and Capobianco, C.J., 1981. Phosphorus and the rare earth elements in felsic magmas: an assessment of the role of apatite. Geochim. Cosmochim. Acta, 45: $2349-2358$.

Watson,E.B. and Ryerson, F.J., 1986. Rutile saturation in magmas: implications for $\mathrm{Nb}-\mathrm{Ti}$-Ta depletion in orogenic magmas. EOS, 67: 412.

Wendlandt, R.F. and Harrison, W.J., 1979. Rare earth partitioning between immiscible carbonate and silicate liquids and $\mathrm{CO}_{2}$ vapor: results and implications for the formation of light rare earth-enriched rocks. Contrib. Mineral. Petrol., 69: 409-419.

Wheller, G.E., Varne, R., Foden, J.D. and Abbott, M., 1987. Geochemistry of Quaternary volcanism in the Sunda-Banda arc, Indonesia, and three-component genesis of island-arc mafic magmatism. In: S.D. Weaver 
and R.W. Johnson (Editors), Tectonic Controls on Magma Chemistry. J. Volcanol. Geotherm. Res., 32: 137-159.

White, W.M. and Dupre, B., 1986. Sediment subduction and magma genesis in the Lesser Antilles: isotopic and trace element constraints. J. Geophys. Res., 91: 5927-5942.
Wood, D.A., Joron, J.L. and Treuil, M., 1979. A re-appraisal of the use of trace elements to classify and discriminate between magma series erupted in different tectonic settings. Earth Planet. Sci. Lett., 45: 326-336.

Wright, T.L., 1974. Presentation and interpretation of chemical data for igneous rocks. Contrib. Mineral. Petrol., 48: 233-248. 